\title{
Effect of the Trusted Taxpayer Designation on Corporate Tax Avoidance Behaviour: Evidence from Korea
}

\author{
Jung-Wha Suh, Ho-Young Lee*, Arnold Edward Kuk and Hyunsoo Ryu
}

\begin{abstract}
Manuscript type: Research paper

Research aims: This study focuses on the efficacy of the trusted taxpayer system in Korea by examining whether firms designated as trusted taxpayers are more likely to pay taxes faithfully, and consistently when compared to firms that are not designated.

Design/Methodology/Approach: This study uses the ordinary least squares (OLS) method, and specifically, the trusted taxpayer designation as an indicator of tax compliance while the book-tax difference (BTD), and the discretionary BTD are used as a measure of tax avoidance.

Research findings: Results show that firms designated as trusted taxpayers are less likely to avoid taxes than firms not designated. Among firms that are designated as trusted taxpayers, it appears that firms with CEOs who come from founding families, firms that are non-SMEs (other than small and medium sized firms defined by the Small Business Act of Korea), and firms whose majority shareholder ownership is greater than the median, are less likely to avoid taxes.
\end{abstract}

\footnotetext{
* Corresponding author: Ho-Young Lee is a Professor at the School of Business, Yonsei University, 50 Yonsei-ro Seodaemun-gu, Seoul, 03722, Republic of Korea. Email: hylee@yonsei.ac.kr JungHwa Suh is a Researcher at the Yonsei Business Centre for Global Business Ethics and Responsibility, Yonsei University, 50 Yonsei-ro Seodaemun-gu, Seoul, 03722, Republic of Korea. Email: suzukiyu81@yonsei.ac.kr

Arnold Edward Kuk holds a Master Degree from the School of Business, Yonsei University, 50 Yonsei-ro Seodaemun-gu, Seoul, 03722, Republic of Korea, and a Master Degree in Economics from Purdue University, UK. Email: aleksay85@gmail.com

Hyunsoo Ryu holds a PhD from the Department of Accounting, Graduate School of Dongguk University, 30 pildong-ro-1, Jung-gu, Seoul, 04620, Republic of Korea. Email: ryuhyunsoo86@ gmail.com
}

https:// doi.org/10.22452/ajba.vol12no2.5 
Theoretical contribution/Originality: To the best of our knowledge, this study is the first to use a tax avoidance measure to examine the effect of the trusted taxpayer designation on corporate tax avoidance by comparing firms that are designated and firms that are not designated as trusted taxpayers.

Practitioner/Policy implications: This study shows that firms designated as trusted taxpayers are less likely to avoid taxes than firms that are not designated. This implies that the current trusted taxpayer system implemented by the Korean tax authority is effective and should be promoted.

Research limitations: The Korean tax authority announces the designation of trusted taxpayers separately for corporate businesses and self-employed businesses. The results of this study are confined to the data of corporate businesses only.

Keywords: Book-Tax Difference, Discretionary BTD, Tax Authorities, Tax Avoidance, Trusted Taxpayers

JEL Classification: $\mathrm{H} 26$

\section{Introduction}

In their effort to encourage tax compliance among business firms, many countries have relied on the tax policy which emphasises on the punitive approach rather than a rewarding approach, as a measure. However, a recent stream of research (Alm, Jackson \& Mckee, 1992; Torgler, 2003; Andreoni, Harbaugh, \& Vesterlund, 2003; Pickhardt \& Prinz, 2014) have suggested that tax authorities can induce better tax compliance by rewarding the taxpayers rather than by punishing them. Recently, Korea has introduced a new tax policy called the trusted taxpayer's system. It is a system that differentiates itself from other tax policies by focusing more on rewarding faithful tax payments rather than on punishing tax avoidances. Although a reward system inevitably requires extra financial outlay from the tax authority, the National Tax Service (NTS) of Korea has announced that it intends to expand and continue with the system.

To minimise the negative impact of tax avoidance and to promote an environment of fair taxation, the NTS conducts an annual tax investigation among firms. When a firm is caught evading taxes, it faces both the financial and reputational consequences, such as paying additional taxes on top of any unpaid amount and public exposure as a tax-evading firm. By contrast, when the investigation concludes that a 
firm is a faithful taxpayer, it earns a designation as a trusted taxpayer, and receives several benefits such as tax points and an exemption from tax investigation for three years, including the year of designation. A firm that is designated as a trusted taxpayer can increase its value, not only through receiving tax benefits, but also by promoting its transparency in the capital market. Naturally, such benefits would induce the designated firms to pay taxes faithfully and consistently, just as the NTS desires.

Unfortunately, recent news noted in the Korean media have indicated that the reality may not conform to the desires of the NTS. On March 5, 2019, Lee (2019), in the daily NTN, a Korean news media, reported that 108 individual trusted taxpayers have been deprived of their status since 2015. There have also been allegations against executives of designated firms for being involved in tax avoidance during the investigation exemption period (Shin, 2019; Ahn, 2019). All these articles suggest a possibility that the designated firms may take advantage of the trusted taxpayer system for the purpose of avoiding taxes.

This study therefore, aims to examine whether firms designated as trusted taxpayers were more likely to pay taxes faithfully and continually when compared to other firms. Herein, we question the effectiveness of the current trusted taxpayer designation system in Korea. Additionally, this study also examines the difference in tax avoidance behaviour between firms designated as trusted taxpayers and other firms in terms of management characteristics and governance structure.

In the context of this study, one would expect to observe a negative relation between the designation and tax avoidance for the following reasons. First, the rewards received by the designated firms would serve as a strong incentive for them to be faithful taxpayers. Studies in psychology (Nagin, 1990; Falkinger \& Walther, 1991; Smith \& Stalans, 1991; Pickhardt \& Prinz, 2014) have suggested that rewarding taxpayers is more effective than punishing them, for the purpose of tax compliance. Second, recent studies have suggested that firms involved in socially responsible activities are less likely to avoid taxes. While the scope of the socially responsible activity is not definite, it is deduced that tax avoidance is a socially irresponsible activity (Landolf, 2006; Williams, 2007; Avi-Yonah, 2008; Hasseldine \& Morris, 2013). For example, when receiving the trusted taxpayer citation, the CEO of Medtronic Korea, stated that faithful tax payment helps the nation and represents Medtronic's mission of being socially responsible (Kim, 2016). This 
meant that firm executives understood the designation as the successful performance of a socially responsible activity. Accordingly, executives of firms designated as trusted taxpayers would also be less willing to avoid taxes after being bestowed with the designation when compared to those firms not designated as trusted taxpayers.

In contrast, tax avoidance as a business strategy to maximise firm profits has become commonplace, and even an integral part of businesses today (Desai \& Dharmapala, 2006). Studies (Graham, Hanlon, Shevlin, \& Shroff, 2014) have indicated that tax avoidance strategies are often considered by firms as a way to increase financial earnings, thereby resulting in improved firm reputation and share prices. Some executives even view tax avoidance as their fiduciary duty towards their shareholders, hence they would actively engage in tax strategies so as to reduce the tax burden (Fisher, 2014). Thus, if firms' desire to maximise shareholder interest is greater than the incentives provided by the trusted taxpayer designation, the designation could have negligible relations on tax avoidance.

Using the trusted taxpayer designation as an indicator variable and the measure of tax avoidance as the dependent variable, we find that firms designated as trusted taxpayers are less likely to avoid taxes when compared to other firms. This result is in accordance with the expectations of the Korean tax authority; the current trusted taxpayer system is successful in inducing taxpayers to pay taxes faithfully and continually. The results of our empirical analysis highlighted two issues. First, firms designated as trusted taxpayers are less likely to avoid taxes when compared to other firms. Second, tax avoidance among firms designated as trusted taxpayers is significantly lower for firms that are managed by CEOs from founding families, non-SME firms and firms with majority shareholder ownership that is greater than the median.

This paper contributes to the current literature by providing two practical implications. First, the outcome derived from this study adds to the existing literature which focusses on the legal system and its effect on taxpayer behaviours. This study also extends on previous findings by providing evidence derived from a system of positive and negative incentives and the reward and penalty system in the context of tax laws. The results also provided evidence showing the benefits of a positive incentive system that encourages taxpayers to engage in faithful and ethical behaviours. This evidence can be applied by the regulatory authorities and policy makers to design and monitor their respective tax systems around the world. Further, the outcome derived from this study 
is also beneficial to investors and creditors who rely on firms' financial reports for their decision-making. The empirical evidence drawn from this study highlighted that financial reporting by designated taxpayers is more reliable than those reported by non-designated firms, thereby avoiding information asymmetry.

The remainder of this paper is organised as follows: Section 2 looks at Korea's current trusted taxpayer system and the related studies done in the past so as to develop the hypotheses. Section 3 describes the research model and the sample selection process. Section 4 presents the empirical results and Section 5 concludes.

\section{Institutional Background, Literature Review, and Hypothesis Development}

\subsection{Regulations Related to Trusted Taxpayer Designation}

In an effort to induce firms to pay taxes faithfully, many countries such as the United States, focus on imposing a strict penalty on tax avoiding firms by conducting rigorous tax investigations from time to time. In the context of Korea, the authority not only focusses on penalising the tax avoiding firms, but also on providing various tax benefits to firms that voluntarily pay taxes faithfully. By examining the effect of the trusted taxpayer system on the faithful taxpayers ability to make tax payments in Korea, this study sheds light on the need for other countries to consider adopting a similar system so as to induce tax compliances.

Currently, the National Tax Service of Korea utilises a system that designates certain firms as trusted taxpayers. The designation is bestowed by the judging committee of the National Tax Service of Korea based on the results of the tax investigations, and the evaluation of the firms that are recommended by local tax authorities or the firms themselves. A public hearing is conducted before the Ministry of Strategy and Finance after which a final designation is then assigned. Once designated, the trusted taxpayers (firms) would receive various benefits. The criteria for firms to be considered as a candidate for the trusted taxpayer designation are: firms must be ongoing entrepreneurs for at least three years, and these firms must pay corporate taxes in an amount that is greater than 50 million Korean won (KRW), in the case of corporate businesses. For individual businesses, the corporate taxes must be greater than 5 million KRW. 
Small business firms can also participate. Firms with less than five full-time employees fall into the category of small businesses (10 if the firm is in the following industries: manufacturing, mining, construction, or transportation). In addition, the total assets for corporate businesses must not exceed three billion KRW while the yearly income for individual businesses must not exceed one billion KRW. Once designated, these firms receive several benefits from the government. First, they are exempted from tax investigations for three years. Second, they receive additional points upon being examined and evaluated by the Korean governmental organisations such as the Ministry of Small and Medium-sized Enterprises and Startups, the Public Procurement Service and the Trust Guarantee Funds. Third, they receive special treatments regarding tax issues. Specifically, being a trusted taxpayer offers these firms some extenuating benefits when they are in violation of some tax regulations. The Korean tax authority provides such benefits to trusted taxpayers in the hope of promoting faithful tax payments. This study investigates the efficacy of the trusted taxpayer system in Korea. Specifically, it aims to provide evidence highlighting the influence of the trusted taxpayer designation on the faithful tax payments of firms in Korea. The outcome should interest the Korean regulators.

\subsection{Literature Review and Hypothesis Development}

While many studies have examined the effects of tax investigations on firms, not much has been written about the relationship between the trusted taxpayer designation and faithful tax payment behaviour. A stream of tax compliance research (Kaplan, Newberry, \& Reckers, 1997) has proposed that tax authorities use legal means to prevent tax avoidance. In particular, tax authorities have also identified some taxavoiding firms through tax investigations and these are later imposed with economic sanctions such as additional taxes. This approach is based on the deterrence theory of educational psychology (Kinsey, 1992). According to the theory, the increased possibility of getting caught for involvement in illegal activities and the resulting sanctions can effectively curb illegal activities.

On the other hand, a stream of research in psychology has also suggested that reward works better than punishment in curtailing undesirable actions. Alm et al. (1992), for example, found that an increase in the amount of public services on individuals, such as increased tax payments, also increased their compliance rates. In support of this 
observation, Torgler (2003) also shared evidence showing that positive rewards in the Costa Rica tax system also influenced tax compliance. This was based on the assumption that traditional factors, such as additional taxes and tax investigation probabilities, were held constantly. Likewise, Feld and Frey (2007) argued that providing taxpayers with non-monetary rewards, such as better and less costly access to public service rather than monetary rewards, was also likely to raise tax morale. Finally, Nagin (1990), Falkinger and Walther (1991), Smith and Stalans (1991), and Pickhardt and Prinz (2014) noted that the rewarding incentive given to taxpayers was more effective than the punishing system imposed on taxpayers for the need to enhance tax compliance.

A stream of research in social responsibility has also provided evidence to show that firms given the designation of trusted taxpayers were less likely to avoid taxes. It was noted by Huang, Sun and Yu (2017) that socially responsible firms were less likely to expatriate and to avoid paying taxes. This is because they were also responsible for their stakeholders, such as the government, customers and suppliers, in accordance with the stakeholder theory. Lanis and Richardson (2015) and Hasan, Hoi, Wu, and Zhang (2017) also reiterated that social responsibility was associated with lower tax avoidance. Therefore, if firms designated as trusted taxpayers considered their designation as a fulfillment of their social responsibility, as suggested by the executive of Medtronic above, then such firms were also less likely to avoid taxes when compared to firms not designated as trusted taxpayers.

This trusted taxpayer designation system is relatively new in Korea and not many studies have explored this issue. Among such studies is Oh (2009) who found that firms designated as faithful taxpayers were more likely to report lower sales in their operating income ratio, lower sales in their net income before tax ratio, and lower net profit margins as compared to their pre-designation. This result suggests that, following the designation, firm's reported net income and income before tax, have decreased while their revenues increased. This may reflect the earnings management in tax avoidance practices. On the other hand, Suh, Lee and Ryu (2017) examined the association between tax avoidance and trusted taxpayer designation. Their results show that firms are less likely to avoid taxes following their designation. Unfortunately, the aforementioned studies do not provide a coherent conclusion as to the effect of the trusted taxpayer designation on tax avoidance. In their study, Suh et al. (2017) examined firms that were designated as trusted taxpayers in terms of their difference in tax avoidance before and 
after the designation. In this study, we compare a sample of firms that are designated as trusted taxpayers to a sample of firms that are not designated as trusted taxpayers. We assume that the management of these firms that are designated as trusted taxpayers is more likely to be ethical and faithful, thus, we conjecture that firms designated as trusted taxpayers are less likely to avoid taxes than non-designated firms. Based on the discussion above, our first hypothesis is formulated as:

$\mathrm{H}_{1}$ : There is a negative association between firms designated as trusted taxpayers and tax avoidance.

Until recently, there has been little research done on the relation between tax avoidance and firm's executives. Among the past studies conducted, Dyreng, Hanlon and Maydew (2010) reported that top executives play a more important role on their firms' tax planning or strategies than lower level executives. The study also implies that the level of tax avoidance depends on the incentives or characteristics of the CEOs. In another study, Chen, Chen, Cheng and Shevlin (2010) focussed on the unique governance system of family firms. They examined the firms' association with tax aggressiveness. It was observed family firms owned and managed by family members practised a stronger governance. This implies that there is smaller agency conflict between owners and executives. Family owners may face different incentives on their tax aggressiveness when compared to the executives of non-family firms. This was revealed by Chen et al. (2010) whose evidence showed that family firms were less tax-aggressive than non-family firms. The authors further argued that family owners were willing to forego the benefits gained from avoiding taxes in order to avoid potential non-tax costs (e.g., price discounts from non-family shareholders, penalties from the IRS and reputational damage). Based on the discussion above, the second hypothesis is formulated as:

$\mathrm{H}_{2}$ : The negative association between the trusted taxpayer designation and tax avoidance will be more pronounced for firms managed by CEOs from founding families.

$\mathrm{Na}$, Park and Song (2014) measured the degree of tax avoidance between SMEs (small and medium-sized enterprises) and non-SMEs (large firms). They found that the degree of tax avoidance was lower for SMEs than large firms. Unlike the latter, SMEs can take advantage of support programs provided by the government; they also received additional tax benefits, such as tax exemptions and credits. Na et al. 
(2014), therefore argued that SMEs have lower incentives to avoid taxes than non-SME firms. However, when designated as trusted taxpayers, large firms not only received tax benefits, but also enjoyed an improved reputation of corporate transparency, potentially leading to a higher valuation in the stock market. Therefore, it is necessary to examine whether non-SME firms that are designated as trusted taxpayers are more or less likely to avoid taxes than their smaller counterparts. Following the two directional arguments discussed above, the third hypothesis is formulated as:

$\mathrm{H}_{3}$ : The association between the trusted taxpayer designation and tax avoidance will be significantly different between SME firms and non-SME firms.

Lee (2010) suggested that firms with majority shareholder ownership increase the value of the firms by preventing the CEOs from misappropriating the firms' assets, thereby avoiding moral hazards. It was further argued that majority shareholder ownership has a negative association with tax avoidance which then reduces the firms' risk of exposure to tax investigations. In this study, we similarly predict that managers of firms holding majority shareholder ownership would increased their firms' value by avoiding the private use of firm assets, thereby moral laxity. Based on this, the fourth hypothesis is formulated as:

$\mathrm{H}_{4}$ : The negative association between the trusted taxpayer designation and tax avoidance will be more pronounced for firms with higher majority shareholder ownership.

\section{Empirical Models and Sample Selection}

\subsection{Measuring Tax Avoidance}

Prior studies used different methods to measure tax avoidance. This is because the definition (and therefore the range) of tax avoidance is varied, depending on the research purpose (Hanlon \& Heitzman, 2010). Three different tax-related behavioural categories were identified: tax savings, tax avoidance and tax evasion. Tax savings is a practice which ensures the optimal minimisation of tax liability within the framework of tax laws. Tax evasion involves efforts to reduce tax liability through illegal activities, potentially subjecting the individual or firm to penalties in accordance with the Punishment of Tax Offenses Act. On the other hand, tax avoidance is practiced as a result of loopholes existing within 
the framework of the tax law, thereby making this practice legal. Depending on the purpose of the research, the term "tax avoidance" may encompass all three categories mentioned, or it may specifically refer to the practice of using loopholes within the tax law. This study engages the latter definition for tax avoidance.

One of the most common method used to measure tax avoidance is to use the book-tax differences (BTD). It is an approach which takes the difference between the pretax book income and the taxable income, and then it is divided with the beginning total assets. This approach is commonly used because it can estimate tax avoidance without having to acquire the firm's actual tax documents. Mills and Sansing (2000) implicated that greater book-tax differences were associated with increased occurrences of tax investigations. This is achieved by identifying a positive association between the two. However, the booktax difference may also capture some elements of the firm's earnings management (Phillips, Pincus, \& Rego, 2003; Hanlon \& Slemrod, 2009). Desai and Dharmapala $(2006,2009)$ then attempted to resolve this issue by separating the components of the BTD; they were then subjected to the firm's earnings management by regressing each firm's BTD on the firm's total accruals, which captured the effect of its earnings management. The writers then took the residuals from the regression and used it as the discretionary book-tax differences (DD_BTD). The following equations (a) and (b) served as the equations used to compute the BTD and the DD_BTD. In these equations, we interpreted the increase in these measures as an increase in tax avoidance activities. Following prior studies (Mills, Erickson, \& Maydew, 1998; Wilson, 2009), we used both the BTD, and the discretionary BTD as our measures of tax avoidance.

$$
\begin{aligned}
& B T D_{i, t}=Y_{i, t}^{S}-Y_{-}^{T} h_{i, t} \\
& B T D_{i, t}=\beta_{1} T A_{i, t}+\varepsilon_{i, t}
\end{aligned}
$$

where

$$
\begin{array}{ll}
B T D_{i, t} & =\text { Difference between book income and tax income } \\
& =(\text { Book Income-Estimated Tax Income }) / \text { Beginning Total Asset } \\
Y_{i, t}^{S} & =\text { Book Income } \\
Y^{T} \text { hat }_{i, t} & =\text { Estimated Tax Income }
\end{array}
$$


$T A_{i, t} \quad=$ Total Accruals/Beginning Total Asset

$\varepsilon_{i, t} \quad=$ Measure of tax avoidance free of earnings management effect $\left(D D \_B T D_{i, t}\right)$

\subsection{Sample Selection}

In Korea, the NTS announces the list of firms which have been designated as trusted taxpayers on March 3, every year. Therefore, we defined the year in which the firm was designated as the event year. Among the firms which were listed on the Korea Composite Stock Price Index (KOSPI) and the Korean Securities Dealers Automated Quotations (KOSDAQ) during 2009-2015, there were firms that were designated as trusted taxpayers due to the tax authority's tax investigations or based on the firms' self-recommendation. For the purpose of this study, we hereby limit our samples to firms that meet the following conditions:

(1) Firms with data available for extraction;

(2) Firms with financial data available on the KIS-VALUE ${ }^{1}$ and TS- $2000^{2}$ for the entire sample period of study; and

(3) Firms with no administrative issues in the stock market.

For our analysis, we employed a matched control sample of nondesignated firms. Following the protocol provided in Etterdge, Sun, Lee and Anandarajan (2008), each designated firm was matched with three control firms based on firm size, year and industry classification. Our final sample thus consisted of 1,019 firm-years of designated firms and 3,057 firm-years for the control sample. Table 1 illustrates.

$\mathrm{H}_{3}$ requires the definition on what constitutes non-SME firms. Article II of the Small Business Act of Korea provides specifications for small and medium-sized enterprises (SMEs), such as the required net sales amount, size of total assets and percentage of ownership of the company. In this study, we define non-SME firms according to this

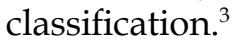

\footnotetext{
${ }^{1}$ KIS-VALUE is a database with data on financial statements and stock information of Korean firms.

${ }^{2}$ TS2000 is a database featuring information on listed firms in the Korean stock market.

${ }^{3}$ Following Section 2 of the Small Business Act in Korea, we define non-SME firms as firms that do not satisfy the following conditions: (1) sales revenue is less than 150 billion Korean won (about 150 million USD), (2) total asset is less than 500 billion Korean won, and (3) majority shareholder ownership is less than 30 per cent.
} 
Table 1: Sample Selection Procedure and Sample Composition

Panel A. Firms designated as trusted taxpayers

\begin{tabular}{cc}
\hline Year & $\begin{array}{c}\text { Firms designated as } \\
\text { trusted taxpayers }\end{array}$ \\
\hline 2009 & 23 \\
2010 & 23 \\
2011 & 21 \\
2012 & 22 \\
2013 & 20 \\
2014 & 22 \\
2015 & 22 \\
\hline
\end{tabular}

Total Sample

153

Panel B. Sample selection procedure

Sample Composition

Number of

observations

Firm-years of firms designated as trusted taxpayers

1,071

during the sample period (2009-2015)

Firm-years of firms designated as trusted taxpayers

more than once during the sample period (2009-2015)

Firm-years without enough information to calculate response or control variables

Total Sample

\subsection{Empirical Models}

We examined the effect of the trusted taxpayers' designation on the likelihood of tax avoidance by using regression models. For all the hypotheses, the dependent variable was the measure of tax avoidance. We specifically followed Desai and Dharmapala (2009) by using booktax differences (BTD), and discretionary BTD (DD_BTD) as stated above for this purpose. Our variable of interest is an indicator variable which takes the value of 1 if a firm has been designated as a trusted taxpayer at least once and 0 for otherwise.

For $\mathrm{H}_{2}, \mathrm{H}_{3}$ and $\mathrm{H}_{4}$, we added an additional variable and its interaction to the model. To test the effect of the presence of a CEO from 
the founding family $\left(\mathrm{H}_{2}\right)$ on tax avoidance among firms designated as trusted taxpayers, we added a CEO from a founding family as the indicator variable (FOUNDER CEO) and its interaction with the TAXPAYER variable. To test the effect of the non-SME firms on tax avoidance among firms designated as trusted taxpayers $\left(\mathrm{H}_{3}\right)$, we added an indicator variable representing the non-SME firms (COC) and its interaction with the TAXPAYER variable. Finally, to test the effect of majority shareholder ownership on tax avoidance among firms designated as trusted taxpayers $\left(\mathrm{H}_{4}\right)$, we added an indicator variable which takes the value of 1 if the firm's majority ownership was greater than the sample median, and 0 for otherwise (Dum_MOWN), and its interaction with the TAXPAYER variable.

$$
\begin{aligned}
\text { TAXAVOID }_{i, t}= & \beta_{0}+\beta_{1} \text { TAXPAYER }_{i, t}+\beta_{2} \text { SIZE }_{i, t}+\beta_{3} \text { INTAN }_{i, t}+ \\
& \beta_{4} \text { INVEN }_{i, t}+\beta_{5} L E V_{i, t}+\beta_{6} \text { FSH }_{i, t}+\beta_{7} \text { MOWN }_{i, t}+ \\
& \beta_{8} \text { AGE }_{i, t}+\sum Y E A R+\sum I N D+\varepsilon_{i, t}
\end{aligned}
$$

$$
\begin{aligned}
\text { TAXAVOID }_{i, t}= & \beta_{0}+\beta_{1} \text { TAXPAYER }_{i, t}+\beta_{2} \text { FOUNDER CEO }_{i, t}+ \\
& \beta_{3} \text { TAXPAYER }_{i, t} \times \text { FOUNDER CEO }_{i, t}+\beta_{4} \text { SIZE }_{i, t}+ \\
& \beta_{5} \text { INTAN }_{i, t}+\beta_{6} \text { INVEN }_{i, t}+\beta_{7} \text { LEV }_{i, t}+\beta_{8} \text { FSH }_{i, t}+ \\
& \beta_{9} \text { MOWN }_{i, t}+\beta_{10} A G E_{i, t}+\sum Y E A R+\sum I N D+\varepsilon_{i, t}
\end{aligned}
$$

$$
\begin{aligned}
\text { TAXAVOID }_{i, t}= & \beta_{0}+\beta_{1} \text { TAXPAYER }_{i, t}+\beta_{2} \text { COC }_{i, t}+\beta_{3} \text { TAXPAYER }_{i, t} \times \\
& \operatorname{COC}_{i, t}+\beta_{4} \operatorname{SIZE}_{i, t}+\beta_{5} \text { INTAN }_{i, t}+\beta_{6} \text { INVEN }_{i, t}+ \\
& \beta_{7} L E V_{i, t}+\beta_{8} \text { FSH }_{i, t}+\beta_{9} \text { MOWN }_{i, t}+\beta_{10} A G E_{i, t}+ \\
& \sum Y E A R+\sum I N D+\varepsilon_{i, t}
\end{aligned}
$$

$$
\begin{aligned}
\text { TAXAVOID }_{i, t}= & \beta_{0}+\beta_{1} \text { TAXPAYER }_{i, t}+\beta_{2} \text { DUM }_{-} \text {MOWN }_{i, t}+ \\
& \beta_{3} \text { TAXPAYER }_{i, t} \times \text { DUM_MOWN }_{i, t}+\beta_{4} \text { SIZE }_{i, t}+ \\
& \beta_{5} \text { INTAN }_{i, t}+\beta_{6} I_{\text {INEN }}+\beta_{7, t} L E V_{i, t}+\beta_{8} F S H_{i, t}+ \\
& \beta_{9} A G E_{i, t}+\sum Y E A R+\sum I N D+\varepsilon_{i, t}
\end{aligned}
$$

where

TAXAVOID = a measure of the level of tax avoidance;

BTD = (income before tax-taxable income) divided by beginning total assets; 
DD BTD

$\begin{aligned} \text { TAXPAYER }= & \begin{array}{l}\text { total accruals by year and industry; } \\ \text { otherwise; }\end{array}\end{aligned}$

FOUNDER CEO = 1 if managed CEOs from founding family, 0 otherwise;

COC = 1 if non-SME firms, 0 otherwise;

Dum_MOWN = 1 if majority shareholder ownership is greater than median, 0 otherwise;

SIZE $\quad=$ natural log of total assets;

INTAN

INVEN

LEV

MOWN

FSH

AGE

YEAR

IND
= intangible assets divided by beginning total assets;

$=$ total inventory divided by beginning total assets;

$=$ total liabilities divided by beginning total assets;

= majority shareholder ownership;

= foreign investor ownership;

$=$ number of days after going public divided by 365;

$=1$ if year of interest, 0 otherwise; and

$=1$ if industry of interest, 0 otherwise.

In this study, we included industry and year fixed effects to address the cross-sectional differences across industry, and time. Following $\mathrm{Na}$ et al. (2014), we then added firm age (AGE) to the model to associate the firm's tax aggressiveness with firm age. Generally, a firm will slow down its growth as it matures, and the firm's level of relative tax cost is also expected to decrease. Thus, we anticipate that older firms would be less likely to pursue aggressive tax strategies.

Within any industry, larger firms (SIZE) tend to have a competitive advantage over smaller firms. Through this advantage, larger firms can use a comparatively more superior tax strategies for its own benefits. This implies that it has a positive association with tax avoidance (Kim \& Jeong, 2006). However, based on the political cost hypothesis, larger firms were more likely to refrain from tax avoidance. From the review of past studies discussed earlier, we deduced that the association can be either way. Since firms' intangible assets (INTAN) were often considered as a measure of the firms' future growth opportunities, it was also deduced that firms with higher growth opportunities were more likely to receive tax benefits. These firms were thus more likely to avoid taxes, even with the tax benefits received because the incentives they had received place them in future anticipation of a decrease in tax payments or an increase in more tax benefits in the future (Gupta \& Newberry, 
1997). It appears that firms with larger inventories (INVEN) were less likely to avoid taxes when compared to firms with smaller inventories (Gupta \& Newberry, 1997). Based on this, we foresee a positive association between intangible assets and tax avoidance, and a negative association between inventory and tax avoidance.

Further to the above, firms with a high leverage ratio (LEV) had been observed to have the incentive to reduce taxable income by using interest payments (Kim \& Jeong, 2006). Since these firms have less incentives to be involved in tax-avoidance, we thus predicted a negative association between the leverage ratio and tax avoidance. In this study, we take the view that firms with high majority shareholder ownership $(M O W N)$, and foreign institutional ownership (FSH) were more likely to have a strong corporate governance. This implied that the shareholders have a more effective monitoring hold on the firms. From this discussion, we also anticipated the coefficients of MOWN and FSH to be negative (Choi, 2013). However, since income after tax is used to pay dividends, the convergence of the interest hypothesis between managers and shareholders may hold. Thus, we expected the sign of MOWN to be positive (Ko \& Park, 2011).

\section{Descriptive Statistics and Empirical Results}

\subsection{Descriptive Statistics}

Table 2 displays the descriptive statistics of the variables used in the analysis. The average of the BTD was noted to be 0.029 for firms designated as trusted taxpayers at least once, and 0.047 for other firms. The value for the discretionary BTD (DD_BTD) was noted as 0.035 for firms designated as trusted taxpayers at least once, and 0.049 for other firms. The table also demonstrates that firms designated as trusted taxpayers at least once were larger (SIZE), have higher foreign ownerships $(F S H)$, and they also have higher majority shareholder ownership $(M O W N)$ than other firms. The t-statistics showed that the difference between the two groups was statistically significant. This implies that firms designated as trusted taxpayers have a stronger corporate governance than other firms.

Table 3 presents the correlations between the variables. The tax avoidance measures, BTD and DD_BTD, had a correlation of 0.960 at the one per cent significance level. The TAXPAYER variable had a correlation of -0.079 and -0.061 with $B T D$ and the discretionary $B T D\left(D D \_B T D\right)$ respectively, at the one per cent significance level. 
Table 2: Descriptive Statistics

\begin{tabular}{|c|c|c|c|c|c|c|}
\hline \multirow[t]{2}{*}{ Variable } & \multicolumn{6}{|c|}{ Firms designated as trusted taxpayers at least once } \\
\hline & Obs. & Mean & SD & Min & P50 & $\operatorname{Max}$ \\
\hline$B T D$ & 1,019 & 0.029 & 0.095 & -0.086 & 0.007 & 0.580 \\
\hline DD_BTD & 1,019 & 0.035 & 0.096 & -0.089 & 0.016 & 0.572 \\
\hline SIZE & 1,019 & 26.112 & 1.492 & 23.830 & 25.709 & 30.863 \\
\hline INTAN & 1,019 & 0.027 & 0.044 & 0 & 0.011 & 0.259 \\
\hline INVEN & 1,019 & 0.125 & 0.103 & 0.001 & 0.096 & 0.463 \\
\hline$L E V$ & 1,019 & 0.382 & 0.205 & 0.051 & 0.360 & 1.064 \\
\hline FSH & 1,019 & 0.084 & 0.124 & 0 & 0.027 & 0.542 \\
\hline MOWN & 1,019 & 0.437 & 0.152 & 0.116 & 0.436 & 0.798 \\
\hline$A G E$ & 1,019 & 8.058 & 1.125 & 3.713 & 8.211 & 9.641 \\
\hline FOUNDER CEO & 1,019 & 0.262 & 0.439 & 0 & 0 & 1 \\
\hline $\mathrm{COC}$ & 1,019 & 0.552 & 0.497 & 0 & 1 & 1 \\
\hline \multirow[t]{2}{*}{ Variable } & \multicolumn{6}{|c|}{ Matching sample } \\
\hline & Obs. & Mean & SD & Min & P50 & Max \\
\hline$B T D$ & 3,057 & 0.047 & 0.095 & -0.023 & 0.016 & 0.580 \\
\hline DD_BTD & 3,057 & 0.049 & 0.095 & -0.089 & 0.022 & 0.572 \\
\hline SIZE & 3,057 & 25.962 & 1.375 & 23.830 & 25.681 & 30.863 \\
\hline INTAN & 3,057 & 0.028 & 0.044 & 0 & 0.011 & 0.259 \\
\hline INVEN & 3,057 & 0.126 & 0.096 & 0.001 & 0.108 & 0.463 \\
\hline$L E V$ & 3,057 & 0.428 & 0.223 & 0.051 & 0.417 & 1.064 \\
\hline FSH & 3,057 & 0.067 & 0.110 & 0 & 0.017 & 0.542 \\
\hline MOWN & 3,057 & 0.425 & 0.155 & 0.112 & 0.418 & 0.798 \\
\hline$A G E$ & 3,057 & 8.152 & 1.096 & 3.713 & 8.371 & 9.641 \\
\hline FOUNDER CEO & 3,057 & 0.216 & 0.412 & 0 & 0 & 1 \\
\hline $\mathrm{COC}$ & 3,057 & 0.605 & 0.488 & 0 & 1 & 1 \\
\hline
\end{tabular}


Effect of the Trusted Taxpayer Designation on Corporate Tax Avoidance Behaviour

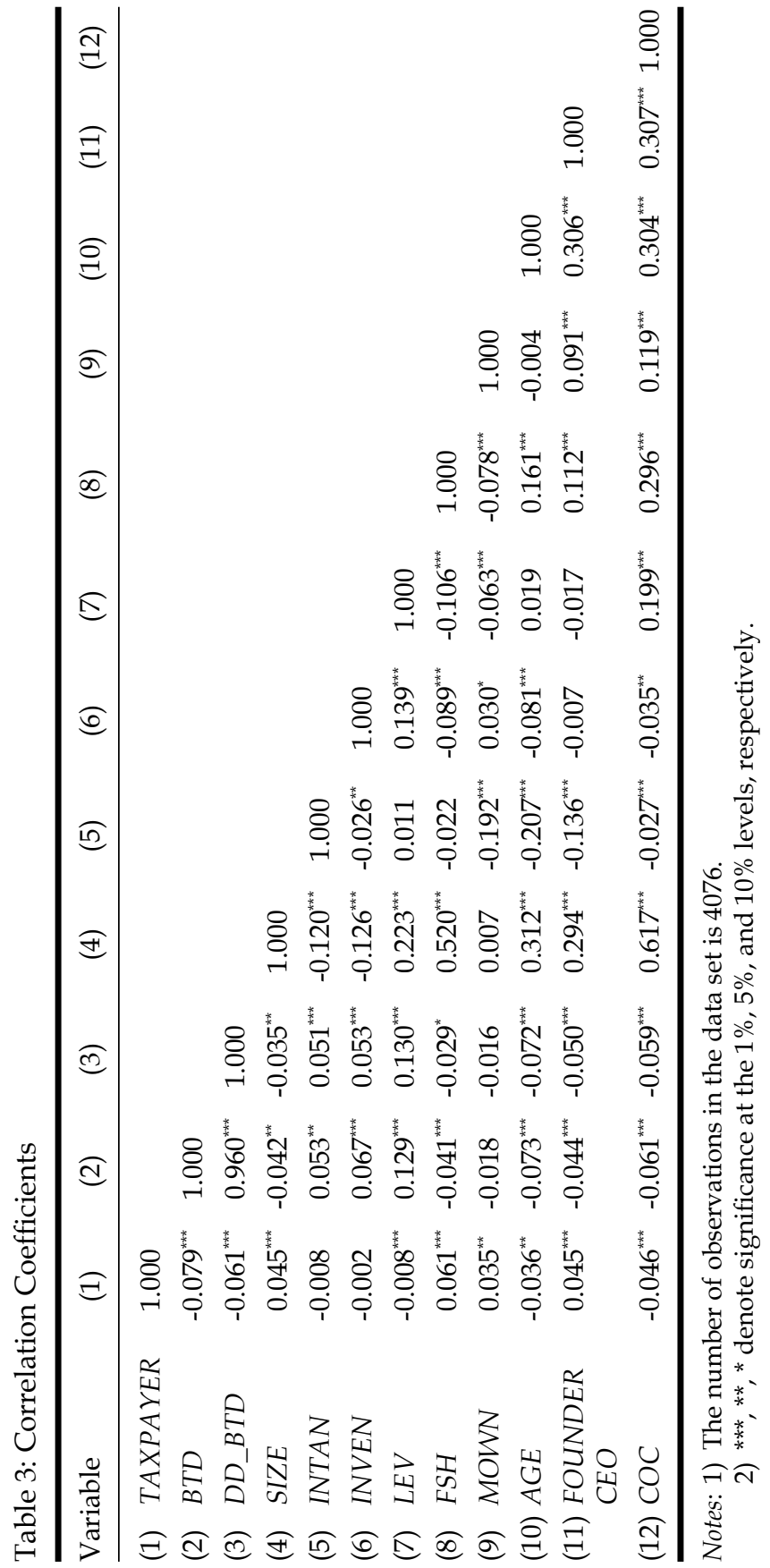




\subsection{Empirical Results}

Table 4 lists the results related to hypothesis $\mathrm{H}_{1}$. Each column shows the results derived from different measures of tax avoidance (BTD, and the discretionary BTD) as the dependent variable. Consistent with our hypothesis, the regression coefficients for our variable of interest are negative, and statistically significant for all measures of the tax avoidance. The outcome suggests that firms are less likely to avoid taxes after being designated as trusted taxpayers. We attribute this finding to the fact that the trusted taxpayer designation has helped the firms to build a reputation of corporate transparency for their external stakeholders as well as the public. This further encourages the firms into believing that they should continue to pay taxes faithfully, thereby promoting transparency, and increasing firm value.

Table 4: Firms Designated as Trusted Taxpayers and Tax Avoidance (H1)

\begin{tabular}{llccr}
\hline \multirow{2}{*}{ Variables } & \multicolumn{4}{c}{ TAXAVOID } \\
\cline { 2 - 6 } & \multicolumn{2}{c}{ BTD } & \multicolumn{2}{c}{ DD_BTD } \\
\hline Intercept & $0.177^{*}$ & $(1.85)$ & $0.171^{*}$ & $(1.77)$ \\
TAXPAYER & $-0.013^{* * *}$ & $(-3.97)$ & $-0.010^{* * *}$ & $(-3.13)$ \\
SIZE & -0.000 & $(-0.19)$ & -0.000 & $(-0.28)$ \\
INTAN & $0.091^{* * *}$ & $(2.70)$ & $0.085^{* * *}$ & $(2.49)$ \\
INVEN & 0.018 & $(1.10)$ & 0.010 & $(0.64)$ \\
LEV & $0.047^{* * *}$ & $(6.38)$ & $0.048^{* * *}$ & $(6.56)$ \\
FSH & 0.008 & $(0.52)$ & 0.016 & $(1.05)$ \\
MOWN & 0.000 & $(0.01)$ & 0.002 & $(0.16)$ \\
AGE & $-0.003^{*}$ & $(-1.79)$ & $-0.003^{* *}$ & $(-2.20)$ \\
\hline Industry and year dummies & \multicolumn{2}{c}{ Included } & \\
No. of observations & \multicolumn{2}{c}{0.128} & & 4,076 \\
Adj. R ${ }^{2}$ & \multicolumn{2}{c}{0.112} \\
\hline
\end{tabular}

Note: This table presents results from the OLS model. ${ }^{* * *},{ }^{* *}$, and ${ }^{*}$ denote significance at the $1 \%, 5 \%$, and $10 \%$ levels, respectively. All $\mathrm{t}$-values are based on two-tailed tests using firm- and year-clustered standard errors.

Table 5 lists the results related to hypothesis $\mathrm{H}_{2}$. Each column showing the results derived from using different measures of tax avoidance (BTD and discretionary BTD) as the dependent variable. Again, the test results are consistent with our hypothesis which states 
Table 5: Effect of CEOs from Founding Families on the Association between Firms Designated as Trusted Taxpayers and Tax Avoidance $\left(\mathrm{H}_{2}\right)$

\begin{tabular}{lcrcr}
\hline \multirow{2}{*}{ Variables } & \multicolumn{4}{c}{ TAXAVOID } \\
\cline { 2 - 6 } & \multicolumn{3}{c}{ BTD } & \multicolumn{2}{c}{ DD_BTD } \\
\hline Intercept & 0.075 & $(1.45)$ & $0.096^{*}$ & $(1.89)$ \\
TAXPAYER & $-0.053^{* * *}$ & $(-10.19)$ & $-0.047^{* * *}$ & $(-9.02)$ \\
FOUNDER CEO & 0.009 & $(1.19)$ & 0.009 & $(1.22)$ \\
TAXPAYER*FOUNDER CEO & $-0.020^{*}$ & $(-1.80)$ & $-0.023^{* *}$ & $(-2.14)$ \\
SIZE & -0.001 & $(-0.32)$ & -0.001 & $(-0.70)$ \\
INTAN & 0.048 & $(1.00)$ & 0.031 & $(0.66)$ \\
INVEN & 0.039 & $(1.76)$ & 0.039 & $(1.78)$ \\
LEV & $0.073^{* * *}$ & $(6.90)$ & $0.073^{* * *}$ & $(6.99)$ \\
FSH & -0.006 & $(-0.26)$ & 0.006 & $(0.25)$ \\
MOWN & 0.023 & $(1.58)$ & 0.021 & $(1.45)$ \\
AGE & -0.002 & $(-0.86)$ & -0.002 & $(-0.91)$ \\
\hline Industry and year dummies & \multicolumn{5}{c}{ Included } \\
No. of observations & \multicolumn{3}{c}{4,076} & 4,076 \\
Adj. R ${ }^{2}$ & \multicolumn{3}{c}{0.090} & 0.081 \\
\hline
\end{tabular}

Note: This table presents results from the OLS model. ***, $* *$, and* denote significance at the $1 \%, 5 \%$, and $10 \%$ levels, respectively. All $\mathrm{t}$-values are based on two-tailed tests using firm- and year-clustered standard errors.

that firms managed by CEOs from founding families would be less likely to avoid taxes, including those designated as trusted taxpayers. This finding shows that firms managed by CEOs from founding families would be less likely to practice tax avoidance so as to avoid the long term risk of tax investigations.

Table 6 shows the regression results for testing hypothesis $\mathrm{H}_{3}$. Similar to our results for $\mathrm{H}_{2}$, the test results here are also negative, and statistically significant. Non-SME firms are less likely to avoid taxes than small and medium-sized firms. This is because such firms wanted higher valuations in the stock market, besides wanting an increased reputation as transparent firms. Consistent with this argument, the results derived from the current study can thus be accepted because even among firms designated as trusted taxpayers, non-SME firms are less likely than small and medium-sized firms in tax avoidance. 
Table 6: Effect of Non-SME firms on the Association between Firms Designated as Trusted Taxpayers and Tax Avoidance $\left(\mathrm{H}_{3}\right)$

\begin{tabular}{|c|c|c|c|c|}
\hline \multirow{3}{*}{$\begin{array}{l}\text { Variables } \\
\text { Intercept }\end{array}$} & \multicolumn{4}{|c|}{ TAXAVOID } \\
\hline & \multicolumn{2}{|c|}{ BTD } & \multicolumn{2}{|c|}{ DD_BTD } \\
\hline & 0.020 & $(0.46)$ & 0.031 & $(0.71)$ \\
\hline TAXPAYER & $-0.026^{* * *}$ & $(-4.54)$ & $-0.020 * * *$ & $(-3.51)$ \\
\hline $\mathrm{COC}$ & -0.001 & $(-0.19)$ & -0.000 & $(-0.09)$ \\
\hline TAXPAYER*COC & $-0.012^{* *}$ & $(-2.24)$ & $-0.015^{* *}$ & $(-1.97)$ \\
\hline SIZE & $0.003^{*}$ & $(1.87)$ & 0.003 & $(1.40)$ \\
\hline INTAN & $0.081^{* *}$ & $(2.02)$ & $0.073^{*}$ & $(1.82)$ \\
\hline INVEN & 0.020 & $(1.06)$ & 0.019 & $(1.00)$ \\
\hline$L E V$ & $0.052^{* * *}$ & $(6.12)$ & $0.055^{* * *}$ & $(6.49)$ \\
\hline FSH & 0.001 & $(0.08)$ & 0.013 & $(0.70)$ \\
\hline MOWN & 0.011 & $(0.08)$ & 0.012 & $(1.03)$ \\
\hline$A G E$ & -0.002 & $(-1.12)$ & -0.003 & $(-1.48)$ \\
\hline Industry and year dummies & \multicolumn{4}{|c|}{ Included } \\
\hline No. of observations & \multicolumn{2}{|c|}{4,076} & \multicolumn{2}{|c|}{4,076} \\
\hline Adj. $R^{2}$ & \multicolumn{2}{|c|}{0.147} & \multicolumn{2}{|c|}{0.133} \\
\hline
\end{tabular}

Note: This table presents results from the OLS model. ***, **, and * denote significance at the $1 \%, 5 \%$, and $10 \%$ levels, respectively. All $\mathrm{t}$-values are based on two-tailed tests using firm- and year-clustered standard errors.

Table 7 shows the regression results after testing hypothesis $\mathrm{H}_{4}$. The test results show that firms with majority shareholder ownership that is greater than the sample median are less likely to avoid taxes when compared with firms having ownership that is less than the sample median. This result thus supports hypothesis $\mathrm{H}_{4}$. The findings show that higher majority shareholder ownership help to curb the executives' tax avoidance behaviour. This is thus deduced as showing that firms with higher majority shareholder ownership are less likely to avoid taxes when compared with firms with lower majority shareholder ownership. This occurs even among firms designated as trusted taxpayers.

\section{Conclusion}

This study examined the efficacy of the Korean trusted taxpayer system by investigating whether or not firms that are designated as trusted 
Table 7. Effect of Majority Shareholder Ownership on the Association between Firms Designated as Trusted Taxpayers and Tax Avoidance (Hypothesis 4)

\begin{tabular}{lcccr}
\hline \multirow{2}{*}{ Variables } & \multicolumn{5}{c}{ TAXAVOID } \\
\cline { 2 - 5 } & \multicolumn{3}{c}{ BTD } & \multicolumn{2}{c}{ DD_BTD } \\
\hline Intercept & 0.045 & $(0.85)$ & 0.079 & $(1.53)$ \\
TAXPAYER & $-0.064^{* * *}$ & $(-8.89)$ & $-0.055^{* * *}$ & $(-7.80)$ \\
Dum_MOWN & $0.015^{* *}$ & $(2.36)$ & $0.016^{* * *}$ & $(2.59)$ \\
TAXPAYER*Dum_MOWN & $-0.018^{*}$ & $(-1.82)$ & $-0.023^{* *}$ & $(-2.34)$ \\
SIZE & 0.001 & $(0.33)$ & -0.001 & $(-0.24)$ \\
INTAN & $0.083^{*}$ & $(1.79)$ & 0.042 & $(0.92)$ \\
INVEN & 0.037 & $(1.59)$ & 0.037 & $(1.63)$ \\
LEV & $0.076^{* * *}$ & $(6.56)$ & $0.076^{* * *}$ & $(6.76)$ \\
FSH & -0.020 & $(-0.72)$ & -0.004 & $(-0.16)$ \\
AGE & -0.000 & $(-0.12)$ & -0.001 & $(-0.30)$ \\
\hline Industry and year dummies & & & Included & \\
No. of observations & \multicolumn{2}{c}{4,076} & & 4,076 \\
Adj. R ${ }^{2}$ & \multicolumn{2}{c}{0.119} & & 0.108
\end{tabular}

Note: This table presents results from the OLS model. ${ }^{* * *}, * *$, and * denote significance at the $1 \%, 5 \%$, and $10 \%$ levels, respectively. All t-values are based on two-tailed tests using firm- and year-clustered standard errors.

taxpayers pay taxes faithfully. The tax authorities provided tax benefits to such firms including exempting these firms from tax investigations for three years once they had been designated as trusted taxpayers. The expectation of this study is that these benefits would induce such firms to pay taxes faithfully and continuously. In particular, this study examined the difference in tax avoidance between trusted taxpayers and other firms. This study also examined whether CEOs from founding families, non-SME firms and majority shareholder ownership would affect the difference in tax avoidance between the two groups.

Using 4,076 matching firm-years listed in the Korean stock markets from 2009 to 2015, our results are able to display the following outcomes. First, we found that firms that are designated as trusted taxpayers are less likely to avoid taxes. Second, among firms designated as trusted taxpayers, we found that tax avoidance is significantly lower for firms managed by CEOs from founding families, for non-SME firms, and for 
firms with high majority shareholder ownership. Our results further indicate that firms designated as trusted taxpayers fulfill the tax authority's expectations by paying their taxes faithfully. The results obtained in this study show that current firms that are trusted by the taxpayer system are effectively inducing faithful tax payments. Based on this, we argue that the trusted taxpayer system should be promoted among other countries too, so as to induce faithful corporate tax payments.

In order to induce tax compliance practices among firms, countries such as the United States of America tend to use the punishment system on tax avoiders, upon the conducting of rigorous tax investigations. In contrast, the NTS of Korea induces tax compliance by rewarding taxpayers through the provisions of some economic tax benefits, especially for those who have paid their taxes faithfully. In contrast, the reward system can successfully induce voluntary payment of taxes. This result implies that adopting a system that is similar to the trusted taxpayer's system may help many countries, including the USA, to induce their taxpayers to pay taxes voluntarily.

This study uses a proprietary data which are taken from a list of firms designated as trusted taxpayers as listed by the NTS of Korea. The data are found to be useful for examining the effectiveness of the tax policy that can easily be considered in other regimes so as to promote the faithfulness of taxpayers. To the best of our knowledge, the effect of tax policies on firms with trusted taxpayers' designation has never been examined before. Thus, empirical evidence which can support the outcome of this study is limited. Based on this, it is hereby emphasised that the result of this study provides the empirical evidence which addressed the claim. The positive tax system introduced by the Korean government can be described as an effective means for improving the faithfulness of the taxpayers in paying taxes. The policy makers of other countries should consider introducing this tax system for its taxpayers.

This study shows that family firms and non-SMEs are more concerned with non-tax costs such as the potential stock price discounts by investors, the potential penalty imposed by the taxing authority, and the potential reputational damage. Our findings thus reinforced the notion proposed by Desai and Dharmapala (2006) who stated that firms could utilise aggressive tax strategies to mask their earnings management activities. Because investors would protect themselves against potential earnings management that is embedded in the aggressive tax strategies, family owners are more willing to forego the 
tax benefits in order to avoid the price discounts associated with family entrenchment. Furthermore, this study has also provided evidence which shows that firms have considered the reputational cost over tax avoidance. This study thus shows that when weighted against the benefits to tax savings, non-SME firms prefer to enjoy an improved reputation of corporate transparency.

Overall, this study is restrained by the fact that the Korean tax authority applied separate criteria for corporate businesses and selfemployed businesses to be given the trusted taxpayer designation. Thus, our results are confined to the data of corporate businesses only. We are also unable to provide a detailed means for tax avoidance as we only used a composite measure of tax avoidance.

\section{References}

Ahn, S. (2019, April 10). BAT Korea cannot acknowledge the allegation of evading tax worth of $\$ 50$ million... have been designated as trusted taxpayer. Chosun Biz. Retrieved from http://biz.chosun.com/site/data/ html_dir/2019/04/10/2019041002057.html

Alm, J., Jackson, B.R., \& McKee, M. (1992). Deterrence and beyond: Toward a kinder, gentler IRS. In J. Slemrod (Ed.), Why people pay taxes: Tax compliance and enforcement (pp. 311-329). Ann Arbor, MI: University of Michigan Press.

Avi-Yonah, R.S. (2008). Corporate social responsibility and strategic tax behavior. In W. Schon (Ed.), Tax and corporate governance (pp. 183-198). Berlin: Springer.

Andreoni, J., Harbaugh, W.T., \& Vesterlund, L. (2003). The carrot or the stick: Rewards, punishments and cooperation. American Economic Review, 93(3), 893-902. http://dx.doi.org/10.1257/000282803322157142

Chen, S., Chen, X., Cheng, Q. \& Shevlin, T. (2010). Are family firms more tax aggressive than non-family firms? Journal of Financial Economics, 95(1), 4161. http://dx.doi.org/10.1016/j.jfineco.2009.02.003

Choi, B.R. (2013). The affection of the volatility of the short-term tax avoidances on the long-run tax avoidance. Korean Accounting Review, 38(3), 113-147.

Desai, M.A., \& Dharmapala, D. (2006). Corporate tax avoidance and highpowered incentives. Journal of Financial Economics, 79(1), 145-179. http:// dx.doi.org/10.1016/j.jineco.2005.02.002

Desai, M.A., \& Dharmapala, D. (2009). Corporate tax avoidance and firm value. The Review of Economics and Statistics, 91(3), 537-546. http://dx.doi.org/ 10.1162/rest.91.3.537

Dyreng, S.D., Hanlon, M., \& Maydew, E.L. (2010). The effect of executives on corporate tax avoidance. The Accounting Review, 85(4), 1163-1189. http:// dx.doi.org/10.2308/accr.2010.85.4.1163 
Etterdge, M.L., Sun, L., Lee, P., \& Anandarajan, A.A. (2008). Is earnings fraud associated with high deferred tax and/or book minus tax levels? Auditing: A Journal of Practice \& Theory, 27(1), 1-33. http://dx.doi.org/10.2308/aud. 2008.27.1.1

Falkinger, J., \& Walther, H. (1991). Reward versus penalties: On a new policy against tax evasion. Public Finance Quarterly, 19(1), 67-79. http://dx.doi. org/10.1177/109114219101900104

Feld, L.P., \& Frey, B.S. (2007). Tax compliance as the result of a psychological tax contract: The role of incentives and responsive regulation. Law and Policy, 29(1), 102-120. http://dx.doi.org/10.1111/j.1467-9930.2007.00248.x

Fisher, J.M. (2014). Fairer shores: Tax havens, tax avoidance, and corporate social responsibility. Boston University Law Review, 94(1), 337-365.

Graham, J.R., Hanlon, M., Shevlin, T., \& Shroff, N. (2014). Incentives for tax planning and avoidance: Evidence from the field. The Accounting Review, 89(3), 991-1023. http://dx.doi.org/10.2308/accr-50678

Gupta, S., \& Newberry, K. (1997). Determinants of the variability in corporate effective tax rate: Evidence from longitudinal study. Journal of Accounting and Public Policy, 16(1), 1-34. http://dx.doi.org/10.1016/S0278-4254(96) 00055-5

Hanlon, M., \& Heitzman, S. (2010). A review of tax research. Journal of Accounting and Economics, 50(2-3), 127-178. http://dx.doi.org/10.1016/j.jacceco. 2010.09.002

Hanlon, M., \& Slemrod, J. (2009). What does tax aggressiveness signal? Evidence from stock price reactions to news about tax aggressiveness. Journal of Public Economics, 93(1-2), 126-141. http://dx.doi.org/10.2139/ssrn.975252

Hasan, I., Hoi, C-K., Wu, Q., Zhang, H. (2017). Does social capital matter in corporate decisions? Evidence from corporate tax avoidance. Journal of Accounting Research, 55(3), 629-668. http://dx.doi.org/10.1111/1475-679X. 12159

Hasseldine, J., \& Morris, G. (2013). Corporate social responsibility and tax avoidance: A comment and reflection. Accounting Forum, 37(1), 1-14. http://dx.doi.org/10.1016/j.accfor.2012.05.001

Huang, H.H., Sun, L., \& Yu, T. (2017). Are socially responsible firms less likely to expatriate? An examination of corporate inversions. The Journal of the American Taxation Association, 39(2), 43-62. http://dx.doi.org/10.2308/atax51790

Kaplan, S.E., Newberry, K.J., \& Reckers, P.M.J. (1997). The effect of moral reasoning and educational communications on tax evasion intentions. The Journal of American Taxation Association, 19(2), 38-54.

Kim, J., \& Jeong, J. (2006). The effect of corporate financial characteristics in the tax avoidance. Korean Journal of Taxation Research, 23(4), 97-123.

Kim, S. (2016, March 29). Medtronic Korea, Taxpayer's Day awarded trusted taxpayer citation. KMDIA News, Retrieved from http://www.kmdianews. $\mathrm{com} /$ news/articleView.html?idxno $=8565$ 
Kinsey, K.A. (1992). Deterrence and alienation effects of IRS enforcement: An analysis of survey data. In J. Slemrod (Ed.), Why people pay taxes (pp. 259285). Ann Arbor, MI: University of Michigan Press.

Ko, S.S., \& Park, S.S. (2011). A Study on the difference of tax avoidance before and after tax investigation. Korean Journal of Taxation Research, 28(2), 41-65.

Landolf, U. (2006). Tax and corporate responsibility. International Tax Review, 29, 6-9.

Lanis, R., \& Richardson, G. (2015). Is corporate social responsibility performance associated with tax avoidance? Journal of Business Ethics, 127(2), 439-457. http://dx.doi.org/10.1007/s10551-014-2052-8

Lee, K.B. (2010). The effects of a firm's ownership structure on tax avoidance. Korean International Accounting Review 34, 187-216. Retrieved from http:// www.dbpia.co.kr/journal/articleDetail?nodeId=NODE01570913

Lee, Y. (2019, March 5). 108 trusted taxpayers deprived of status for abusing loopholes of the system. Daily NTN. Retrieved from http://www.intn. co.kr/news/articleView.html?idxno $=2004731$

Mills, L.M., Erickson, M., \& Maydew, E. (1998). Investments in tax planning. The Journal of the American Taxation Association, 20(1), 1-20. Retrieved from https:/ / search.proquest.com/docview/211139522?pq-origsite=gscholar

Mills, L.F., \& Sansing, R.C. (2000). Strategic tax and financial reporting decisions: Theory and evidence. Contemporary Accounting Research, 17(1), 85-106. http://dx.doi.org/10.1111/j.1911-3846.2000.tb00912.x

Na, H.J., Park, S.O., \& Song, H.J. (2014). A study on tax avoidance of SMEs. Asia Pacific Journal of Small Business, 36(2), 89-107.

Nagin, D.S. (1990). Policy options for combatting tax noncompliance. Journal of Policy Analysis and Management, 9(1), 7-22. http://dx.doi.org/10.2307/ 3325110

National Tax Service. $(2017,2018)$. Trusted taxpayer benefits guide. Retrieved from https://www.nts.go.kr/site/site_03.asp

Oh, K.S. (2009). Study on the effectiveness of the tax investigation exemption program. Journal of Taxation and Accounting 10(1), 9-33.

Phillips. J., Pincus, M., \& Rego, S.O. (2003). Earnings management: New evidence based on the deferred tax expense. The Accounting Review, 78(2), 491-521. http://dx.doi.org/10.2308/accr.2003.78.2.491

Pickhardt, M., \& Prinz, A. (2014). Behavioral dynamics of tax evasion - A survey. Journal of Economic Psychology, 40(February), 1-19. http://dx.doi. org/10.1016/j.joep.2013.08.006

Shin, K. (2019, April 26). Deviation of trusted taxpayers? The NTS investigates the representative Jung Hyun Ho of Medi Tox. Sejungllbo. Retrieved from http://www.sejungilbo.com/news/articleView.html?idxno=16436

Smith, K.W., \& Stalans, L.J. (1991). Encouraging tax compliance with positive incentives: A conceptual framework and research directions. Law \& Policy, 13(1), 35-53. http://dx.doi.org/10.1111/j.1467-9930.1991.tb00056.x 
Suh, J.H., Lee, H.Y., \& Ryu, H.S. (2017). A study of tax evasion before and after trusted taxpayer designation. Korean Accounting Journal 26(4), 77-112. http://dx.doi.org/10.24056/KAJ.2017.06.006

Torgler, B. (2003). Beyond punishment: A tax compliance experiment with taxpayers in Costa Rica. Revista de AnálisisEconomico, 18(1), 27-56.

Williams, D.F. (2007). Developing the concept of tax governance. London: KPMG.

Wilson, R. (2009). An examination of corporate tax shelter participants. The Accounting Review, 84(3), 969-999. http://dx.doi.org/10.2308/accr.2009. 84.3.969 